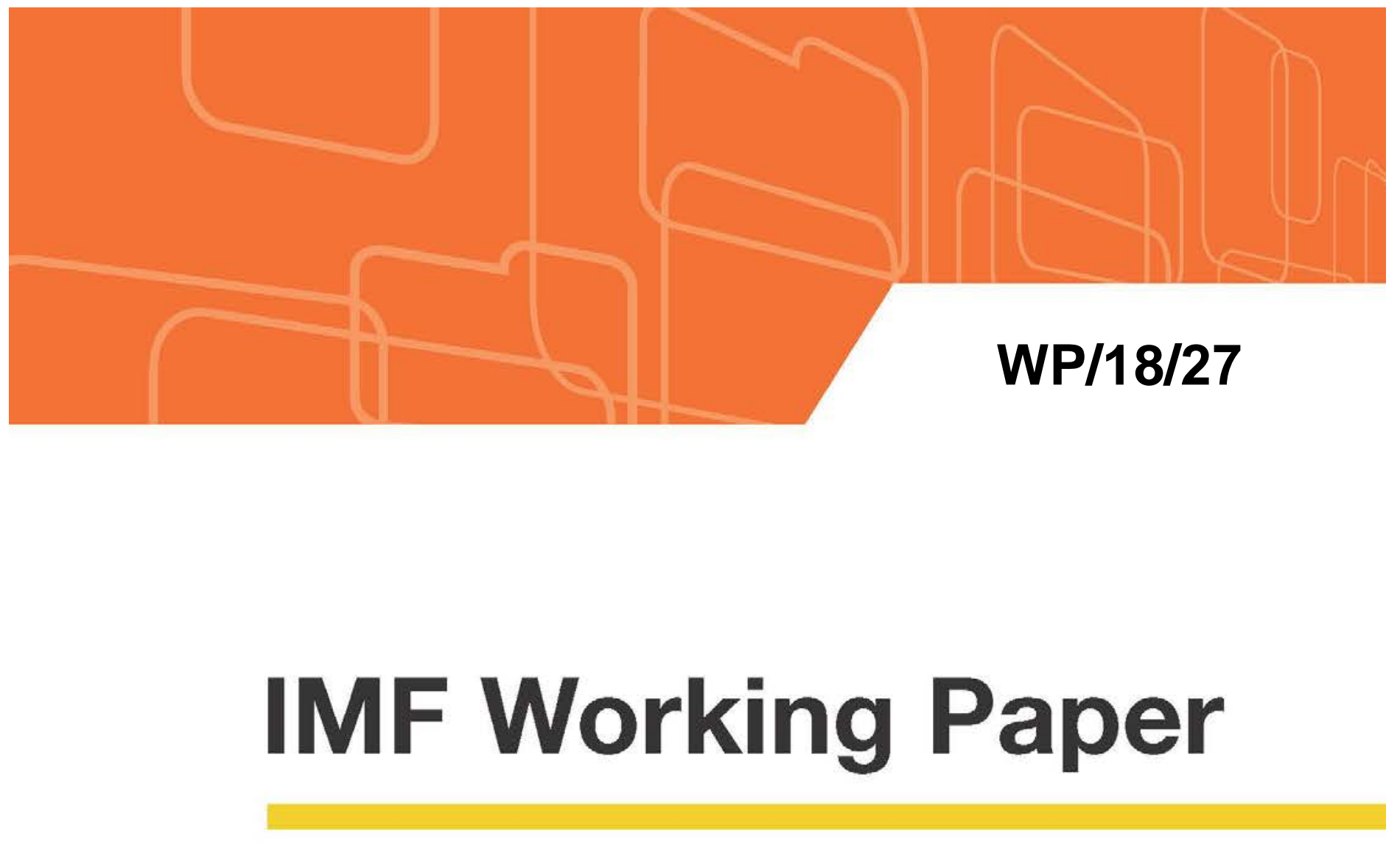

\title{
Morocco: A Practical Approach to Monetary Policy Analysis in a Country with Capital Controls
}

by Mokhtar Benlamine, Aleš Buliř, Meryem Farouki, Ágnes Horváth, Faical Hossaini, Hasnae El Idrissi, Zineb Iraoui, Mihály Kovács, Douglas Laxton, Anass Maaroufi, Katalin Szilágyi, Mohamed Taamouti, and David Vávra

IMF Working Papers describe research in progress by the author(s) and are published to elicit comments and to encourage debate. The views expressed in IMF Working Papers are those of the author(s) and do not necessarily represent the views of the IMF, its Executive Board, or IMF management. 


\title{
IMF Working Paper
}

Research Department

\section{Morocco: A Practical Approach to Monetary Policy Analysis in a Country with Capital Controls}

\section{Prepared by Mokhtar Benlamine, Aleš Bulíř, Meryem Farouki, Ágnes Horváth, Faical Hossaini, Hasnae El Idrissi, Zineb Iraoui, Mihály Kovács, Douglas Laxton, Anass Maaroufi, Katalin Szilágyi, Mohamed Taamouti, and David Vávra}

Authorized for distribution by Douglas M. Laxton

February 2018

IMF Working Papers describe research in progress by the author(s) and are published to elicit comments and to encourage debate. The views expressed in IMF Working Papers are those of the author(s) and do not necessarily represent the views of the IMF, its Executive Board, or IMF management.

\begin{abstract}
The Central Bank of Morocco has been working on developing a Forecasting and Policy Analysis System (FPAS) to support a gradual move toward a more flexible exchange rate regime and the eventual adoption of a full-fledged inflation-targeting (IT) regime. At the center of the FPAS is a quarterly projection model that was tailored for two different types of exchange rate regimes. Presently, the fixed exchange rate model version is to be used during the pre-IT period, while the flexible exchange rate model version is to be used to prepare alternative scenarios for monetary policy decision makers to discuss the potential policy implications of shocks under an IT regime.

JEL Classification Numbers: E52, E47, C51

Keywords: Monetary policy, forecasting and simulation, model construction

Authors’ E-Mail Addresses: abulir@imf.org, b.mokhtar@bkam.ma, m.farouki@bkam.ma, aha2027@gmail.com, h.facial@bkam.ma, h.elidrissi@bkam.ma, z.iraoui@bkam.ma, dlaxton@imf.org, an.maaroufi@bkam.ma, katalin.szilagyi@ogresearch.com, m.taamouti@bkam.ma, david.vavra@ogresearch.com
\end{abstract}




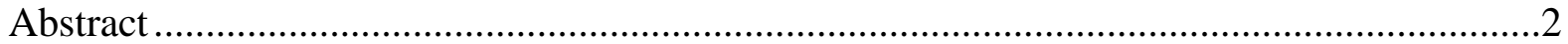

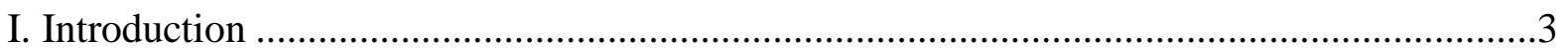

II. Morocco: Monetary Independence Under a Peg and Capital Controls...............................4

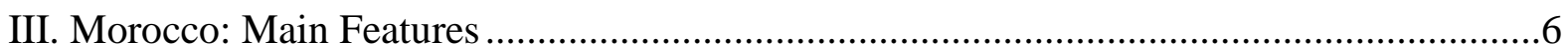

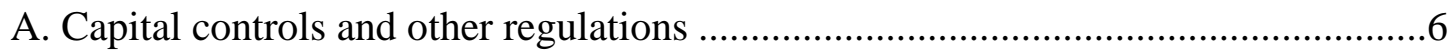

B. The fixed exchange rate regime and monetary policy .........................................6

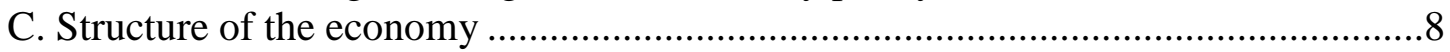

IV. The Moroccan Quarterly Projection Model (MQPM)..................................................10

A. A model for transition .................................................................................... 10

B. Special Features of the Moroccan QPM Model ..................................................11

C. Selected Impulse Response Functions ...............................................................14

V. Conclusions and the Policy Uses of the QPM in Morocco.............................................16

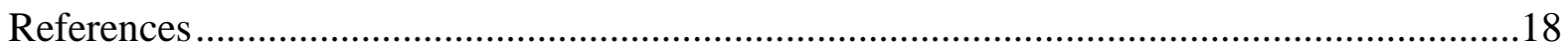

Tables

1. Modeling Solutions to Regime Differences.................................................................11

2. The MQPM Structure Under the Fixed Exchange Rate Regime ......................................13

Figures

1. Morocco: Macroeconomic Developments ................................................................

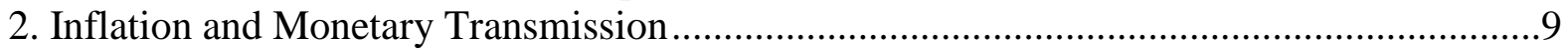

3. A Positive One-Percent shock to Euro Area Inflation ...................................................12

4. An Increase in Household Consumption .........................................................................14

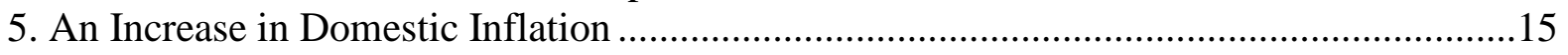

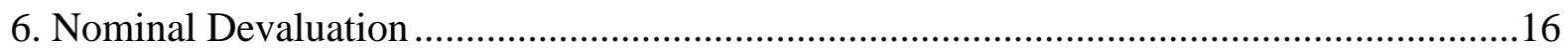

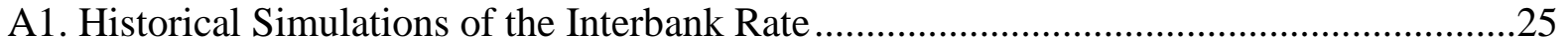

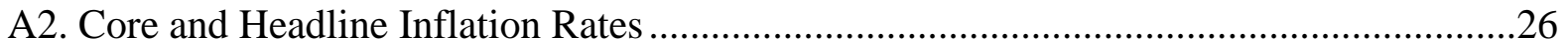

A3. Domestic Demand Growth................................................................................27

Annexes

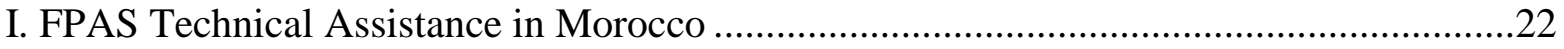

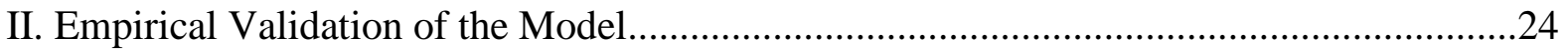

III. Abbreviations Used in Table 2. .............................................................................28 


\section{INTRODUCTION}

Morocco is expected to become the first emerging market country to have adopted an inflation-targeting (IT) framework from a position of strength, that is, without a domestic financial crisis or external pressure. Other countries adopted IT because "monetary targets abandoned them" (Canada), the country needed a disinflation mechanism (Chile), a financial crisis made a peg non-credible (Czech Republic), or because other monetary frameworks failed to provide macroeconomic stability (New Zealand). Morocco's situation is different: the exchange rate peg has not been under pressure and the economy has recorded stable real GDP growth. In this paper we describe some of the choices the Bank Al-Maghrib (BAM) has made to accommodate the gradual monetary policy reforms. These choices made by the BAM present useful lessons for countries contemplating a gradual regime switch toward inflation targeting.

To address the need for faster economic growth to support its growing population the Moroccan authorities have embarked on a program of a gradual opening up of the economy. Some of the steps that started in the early 2000s included massive infrastructure build up; attracting export-oriented industries by tax and other incentives; measured liberalization of current and capital account flows; far-ranging fiscal, pension, and capital market reforms; education and social reforms; and so on (IMF, 2016a). The authorities also signaled as early as in the mid-2000s their intention to move toward a more flexible exchange rate regime and inflation targeting. It has been argued that such a regime would increase the maneuvering space for macroeconomic policies and cushion the economy from real external shocks, while keeping the dirham competitive. While progress in achieving these objectives slowed down during the Global Financial Crisis, it was rekindled in the early 2010s, supported by extensive domestic consultation and IMF-led technical assistance (IMF, 2015a). Modernization of monetary policy, including a new central bank law and gradual enhancement of the policy modeling framework, has been a crucial part of the reform efforts.

The measured approach to reforms has had its pros and cons. On the one hand, the gradualism has bought time, allowing thorough consultations and preparations. On the other hand, the gradual approach has worked against fast actions and the BAM had to expend sizable resources to operationalize an intermediate regime. For example, the BAM staff, with IMF technical assistance, developed a new Forecasting and Policy Analysis System (FPAS) with two parallel versions of the forecasting model at its core. A fixed exchange rate and foreign exchange (capital) control version is to be used in the current environment and a flexible exchange rate version will be used after the eventual regime switch (see Benlamine and others, forthcoming). ${ }^{1}$

\footnotetext{
${ }^{1}$ In January 2018 the Moroccan government announced a widening of the fluctuation band in which the dirham is traded against the US dollar and euro from \pm 0.3 percent to \pm 2.5 percent. While this adjustment is a part of the gradual, pre-announced process toward a more flexible exchange rate, inflation targeting regime, and the gradual easing of foreign exchange controls (Bank Al-Maghrib, 2016), from the modeling point of view, the exchange rate continues to serve as the nominal anchor and the fixed-rate version of the FPAS framework will be used for the baseline projections.
} 
The rest of the paper is organized as follows. In section II we present the current monetary framework. In section III we give a brief overview of the special features of the Moroccan economy that were to be incorporated in the FPAS. In section IV we present the main differences between the fixed- and flexible-exchange rate versions of the model. Section $\mathrm{V}$ concludes.

\section{Morocco: Monetary IndePendence Under a Peg And Capital Controls}

Following the creation of the dirham in the 1950s, Morocco has combined a fixed exchange rate and capital controls to retain a degree of monetary policy independence. Presently, Morocco pegs the dirham against a basket of the euro and U.S. dollar and limits capital account transactions to keep control over short-run domestic interest rates and other instruments of monetary policy, such as reserve requirements. In other words, the exchange rate serves as a nominal anchor, pinning down the aggregate price level and wage growth.

The above policy mix reflected the empirical observation that no country can achieve simultaneously a fixed exchange rate, free capital mobility, and an independent monetary policy dedicated to domestic goals (Obstfeld and Taylor, 1997; Obstfeld, Shambaugh, and Taylor, 2005; Rey, 2010). The so-called impossible trinity argues that to retain control over short-term interest rates the authorities have two options. First, they can float the exchange rate and identify an alternative nominal anchor, such as an inflation target. ${ }^{2}$ Arbitrage based on flow of capital will ensure that the depreciation or appreciation of a country's currency vis-à-vis another will reflect the nominal interest rate differential between these countries. Second, the authorities may continue pegging the exchange rate and suspend the uncovered interest rate parity condition by limiting the flow of capital in and out of the country. If the capital controls are sufficiently restrictive, a differential between the domestic and world rates can persist without putting pressure on the peg and the country's international reserves.

Morocco’s monetary policy choice has reflected the authorities' long-standing preference for a relatively tightly controlled economic system for capital flows and this choice clearly had its pros and cons. ${ }^{3}$ On the one hand, the approach contributed to overall macroeconomic stability - Morocco has been largely insulated from the global financial cycle, avoiding financial bubbles, build up or unsustainable private, foreign-currency debt, and other issues often observed in emerging market countries with unrestricted flows of capital. ${ }^{4}$ On the other

\footnotetext{
${ }^{2}$ Most advanced and emerging market countries in this group use explicit inflation targets as nominal anchors, while most low-income countries rely on some form of monetary targeting (IMF, 2015b).

${ }^{3}$ Morocco accepted the so-called Article VIII - no restrictions on payments and transfers for current international transactions, no discriminatory currency arrangements or multiple currency practices - in 1993. ${ }^{4}$ Reinhart and Reinhart (2008) argue that capital inflow surges have been associated with a higher likelihood of banking, inflation and currency crises, and contributed to economic and financial instability. Kaminsky and others (2004) show that capital inflows are a primary reason for the procyclicality of macroeconomic policies. On the one hand, Rey (2013) argues that some tool of active capital account management is needed to prevent such outcomes. She argues that "independent monetary policies are possible if and only if the capital account is managed," given that capital flows into and out of emerging markets are mainly driven by global factors. On the
} 
hand, the current regime has limited the government's ability to meet the competitiveness challenge and to absorb external shocks. ${ }^{5}$ The links between monetary instruments and the ultimate macroeconomic objectives have been relatively weak as compared to more open economies and financial markets, while expanding in recent years, remained thin. ${ }^{6}$

The active stabilization role of monetary policy in Morocco has been less pronounced than in countries with a floating exchange rate and an open capital account. Domestic policies have been focused instead on the achievement of the dual external objectives of exchange rate stability and sustainable international reserves. For example, the BAM policy rate moved only 11 times during 2000-2016, while the European Central Bank and Czech National Bank made 43 and 36 adjustments to their key interest rates, respectively. The BAM has instead relied on non-interest instruments of monetary policy, such as reserve requirements.

The dirham hard peg constrained the authorities' range of policy options to respond to real shocks. Terms of trade and real interest rate shocks result in changes in the equilibrium real exchange rate, however, under a peg, the adjustment in the real exchange rate will take place through changes in domestic nominal prices and domestic wages, associated with deeper and longer contractions (Obstfeld and Rogoff, 1995; Edwards and Levy Yeyati, 2005). ${ }^{7}$ The period following the Global Financial Crisis demonstrates this point well. Shifts in the Moroccan equilibrium real exchange rate required a depreciation of about 10 percent and this adjustment came about through the internal devaluation process: price and wage growth below the rate of Moroccan trading partners and subpar real GDP growth.

The economy's transmission mechanism tends to be less effective in the case of a peg and closed capital account than under a flexible exchange rate regime and free capital flows. Interventions in foreign exchange markets leave less scope for the functioning of the conventional interest rate channel and the asset channel, while the nominal portion of the exchange rate channel is fully closed. Regarding the asset channel, capital controls are likely to slow down the development of well-functioning markets for fixed-income securities, equities, and real estate. Furthermore, effectiveness and reliability of the bank lending channel can be constrained by the oligopolistic structure of the banking sector due to barriers to entry into the domestic capital market (Benazzi and Rouiessi, 2017).

\footnotetext{
other hand, Klein and Shambaugh (2013) argue that a country with an open capital account can still gain considerable monetary autonomy by allowing its exchange rate to float.

${ }^{5}$ See Bank Al-Maghrib (2016), p.21.

${ }^{6}$ Bank penetration increased from 43 percent of total population in 2008 to 63 percent in 2015 and banking density (branches per resident) increased by 50 percent during this time (IMF, 2016b). Still, one-quarter of the Morocco's unbanked have cited high costs as the main reason for not having a bank account (Zottel and others, 2014).

${ }^{7}$ Policy recommendations often differ between flexible and fixed regimes. Let us consider a situation when the expected domestic output gap turns negative during the Global Financial Crisis. Under a float the authorities will be expected to quickly loosen monetary policy, supporting nominal (and real) depreciation of the currency. Under a peg, the authorities may choose to tighten monetary conditions to protect the peg. Inflation declines further, thus depreciating the real exchange rate and improving price competitiveness.
} 


\section{Morocco: MAIN FeATURES}

\section{A. Capital controls and other regulations}

Morocco started relaxing its comprehensive system of foreign exchange controls in the 1980s. Most barriers related to exports and imports of goods and services were removed, with the exception of tariffs on cereal imports to protect domestic producers. In 2007 outward capital transactions were relaxed for residents and remittances of capital and related nonresident incomes were liberalized, however, foreign-currency denominated loans need to be authorized by the Moroccan Office of Foreign Exchange. In summary, while restrictions related to inward investments were relaxed significantly, outward restrictions remain binding (Taamouti, 2015), and regarding the Chinn-Ito financial openness index Morocco ranks 141st out of the 182 countries (http://web.pdx.edu/ ito/Chinn-Ito_website.htm).

The existing restrictions have affected investors' perceptions about Morocco, but their impact on overall investment and potential growth is difficult to quantify. Net inflows of portfolio investments have remained insignificant at less than 0.1\% of GDP during the 2007-2015 period. Foreign direct investment in per capita terms increased eight times relative to the pre1980s period, however, it remained low relative to other emerging market countries with more liberal capital accounts (Figure 1).

\section{B. The fixed exchange rate regime and monetary policy}

The Moroccan dirham was pegged to the French franc from the time of independence in 1956 until the Bretton-Woods system collapsed in 1973, followed by a peg to a basket of eight currencies. After a period of high inflation in the 1970s and dirham real appreciation, the currency was devalued several times during the 1980s and early 1990s. In the early 2000s the basket was narrowed to the euro and US dollar with respective weights of 80 percent and 20 percent and in 2015 these weights were changed to 60 percent and 40 percent.

The current peg to the dollar-euro basket has provided a credible nominal anchor for inflation expectations, ensuring inflation stability comparable to industrial countries. Economic growth, however, remained weak and volatile as compared to its peers, partly related to an overvalued real exchange rate in the aftermath of the Global Financial Crises (IMF, 2012; IMF, 2013). This misalignment was resolved through internal devaluation and the substantial decline in global commodity prices during the mid-2010s, and the currency is presently estimated to be broadly in line with economic fundamentals, (IMF, 2016a; Brixiova and others, 2013; Bouzahzah and Bachar, 2014). 
Figure 1. Morocco: Macroeconomic Developments

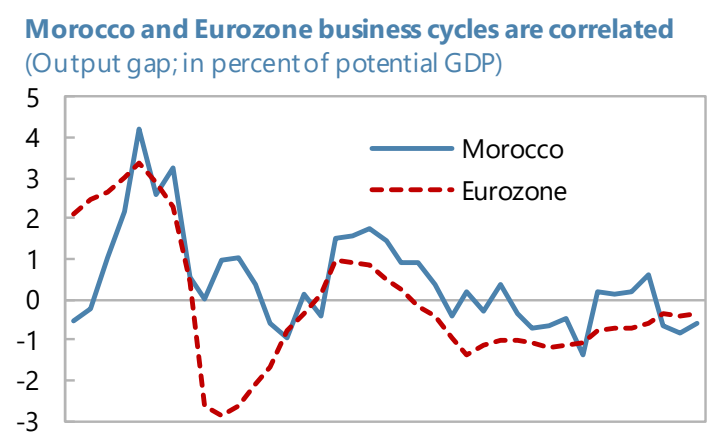

2007Q1 2008Q3 2010Q1 2011Q3 2013Q1 2014Q3 2016Q1

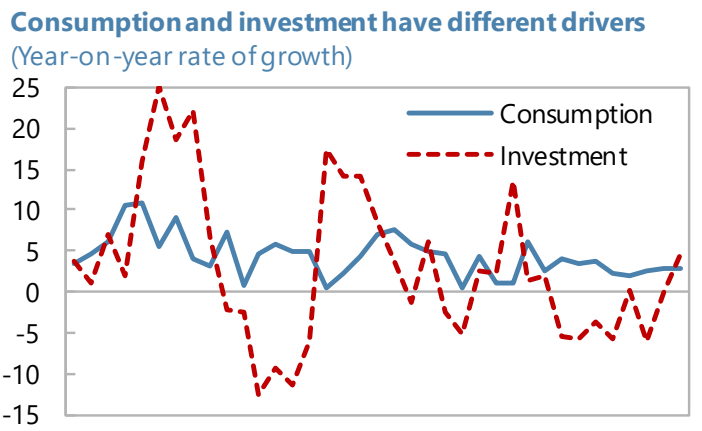

2007Q1 2008Q3 2010Q1 2011Q3 2013Q1 2014Q3 2016Q1

The current acccount narrowed as oil prices declined (In percent of GDP and US\$per barrel)

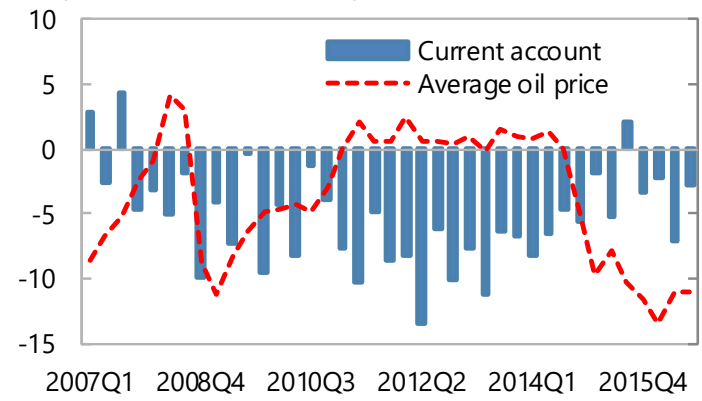

Portfolio investment remains negligible (In percent of GDP)

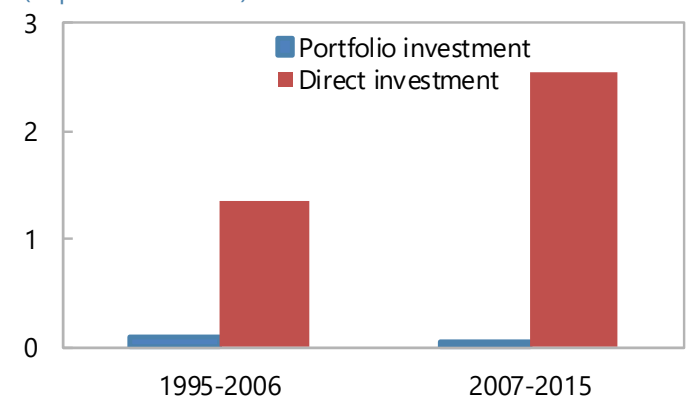

Morocco's agriculture is very volatile (Year-on-year rate of growth)

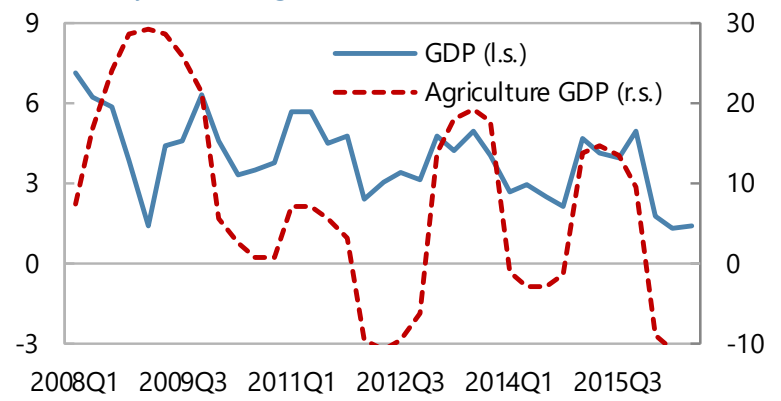

Remittances are a stable source of household income (Year-on-year rate of growth)

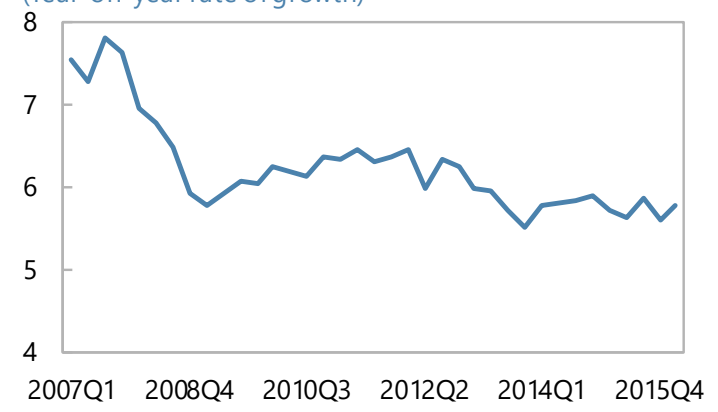

Real exports grow faster than domestic demand (Average year-on-year rate of growth)
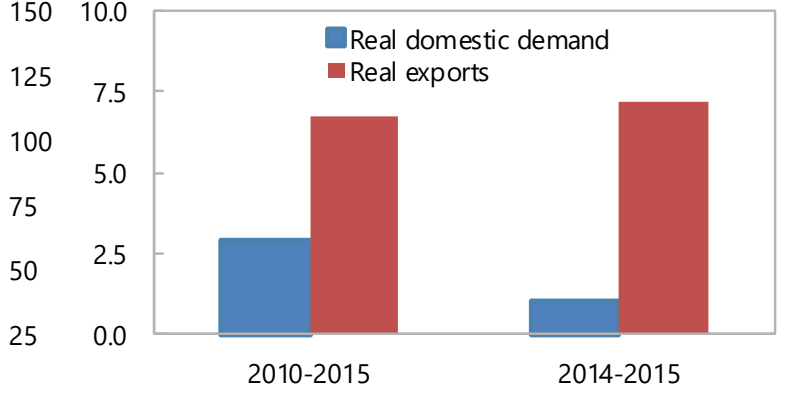

FDI inflows lag behind regional peers

(In US\$ per capita; 1995-2006 and 2007-2015)

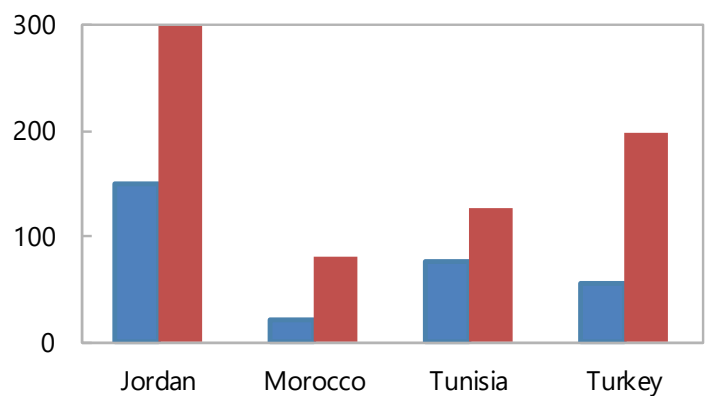

Source: National data and MQPM database. 
From 2006, the operational target of the central bank has been the interbank weighted average rate, which the central bank has managed using two tools: adjusting the key policy rate and changing the required reserve ratio of the banking sector (Taamouti, 2015; Figure 2). The interbank rate has been set with a broad view of achieving price stability, without an explicit inflation target, and supporting economic growth. The partly closed capital account has supported the BAM's efforts to keep the interbank rate at the desired level.

\section{Structure of the economy}

In this section, we present selected features of the Moroccan economy to be reflected in the FPAS framework. First, Morocco is a small open economy, highly sensitive to external developments (e.g. the euro area). This feature requires that the forecasting framework accounts for developments in foreign demand and commodity prices, especially oil and food. Second, domestic agriculture is an important source of output volatility, warranting a decomposition of GDP to agricultural and nonagricultural sectors. Third, the structure of Moroccan value added has begun to change as the automobile and other export-oriented sectors grow faster than domestic demand. Fourth, while investment has been linked to centralized infrastructure projects ${ }^{8}$ and FDI inflows, consumption has been driven by household decisions linked to agricultural production ${ }^{9}$ and inflows of remittances.

Fifth, Morocco has had low headline inflation, comparable to developed economies, averaging only 1.7 percent during 1996-2015. The sizable weight of volatile food items - at 42 percent, the share of food in the CPI basket is more than twice the share as in the Eurozone basket - and items with regulated prices warrants a decomposition of the CPI index to core inflation and other subindexes. Sixth, given the long-term stability of the exchange rate basket, any changes in the euro-dirham exchange rate are quickly translated into core inflation. Seventh, the interbank rate, which has been under the control of the BAM, shares a level principal component with the lending rate and event studies suggest that the policy rate changes are relatively quickly translated into lending rates. The last two stylized facts thus suggest the presence of both significant exchange rate and interest rate channels in Morocco.

8 The construction and public works were the main component of the gross fixed capital formation during the period 2000-2014 (around 50 percent).

${ }^{9}$ Albeit its share in total employment has been slowly declining, the agricultural sector employed almost 40 percent of population in 2015. 
Figure 2. Inflation and Monetary Transmission
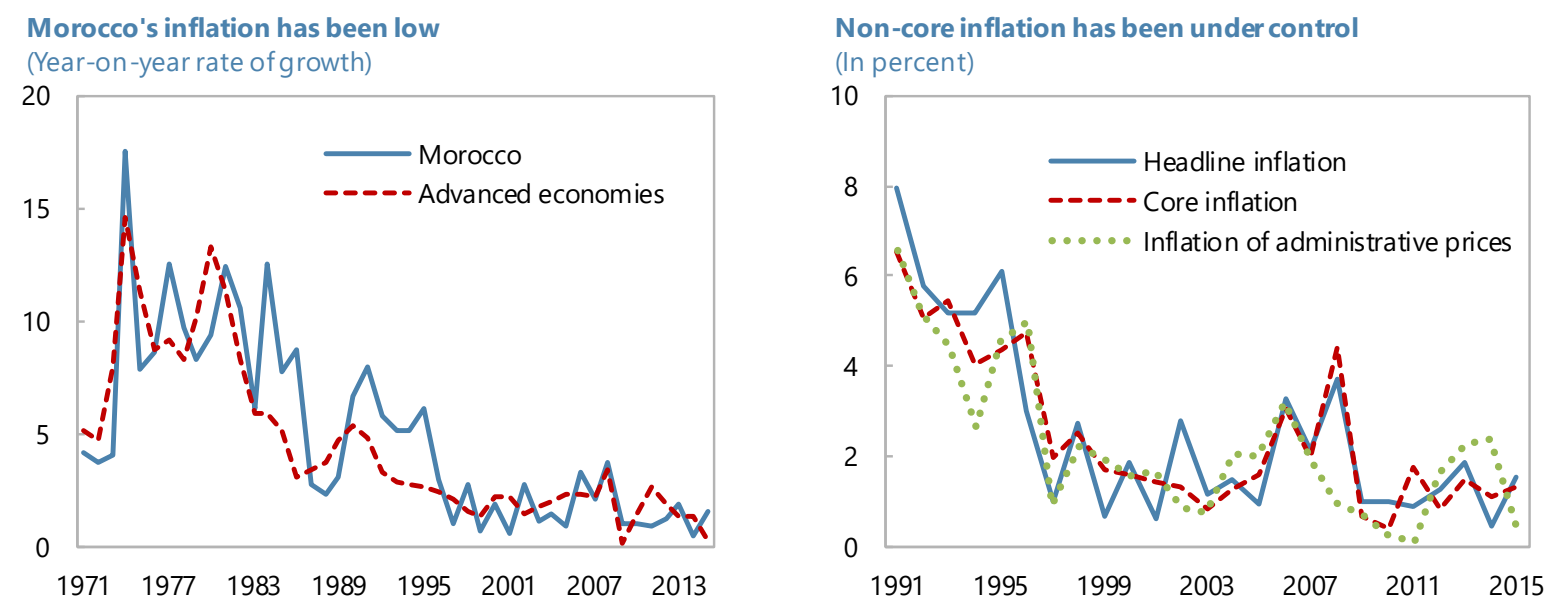

The BAM policy rate has been stable...

(In percent)

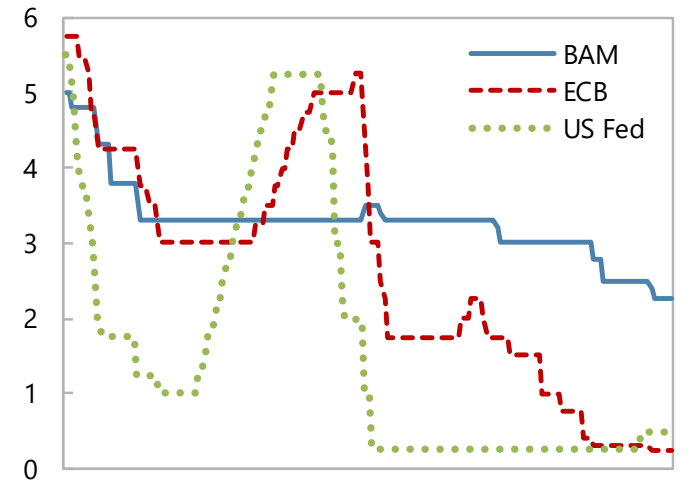

...as BAM relied more on reserve requirement changes (In percent)

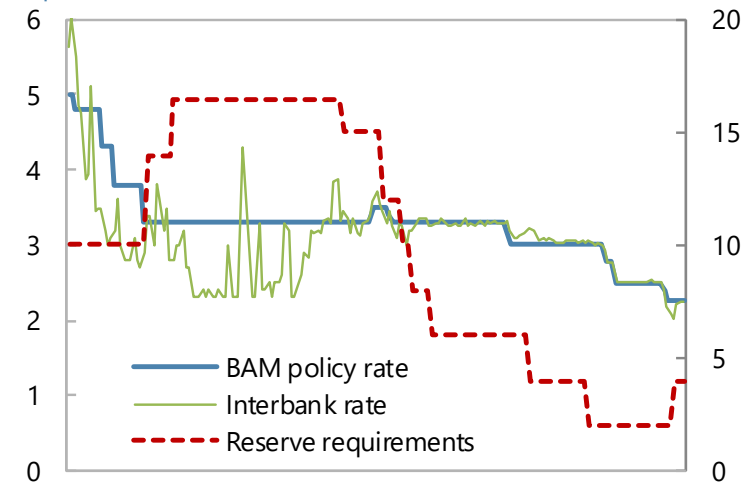

2001M01 2004M01 2007M01 2010M01 2013M01 2016M01

2001M01 2004M01 2007M01 2010M01 2013M01 2016M01

Lending spreads in Morocco have stabilized (In basis points)

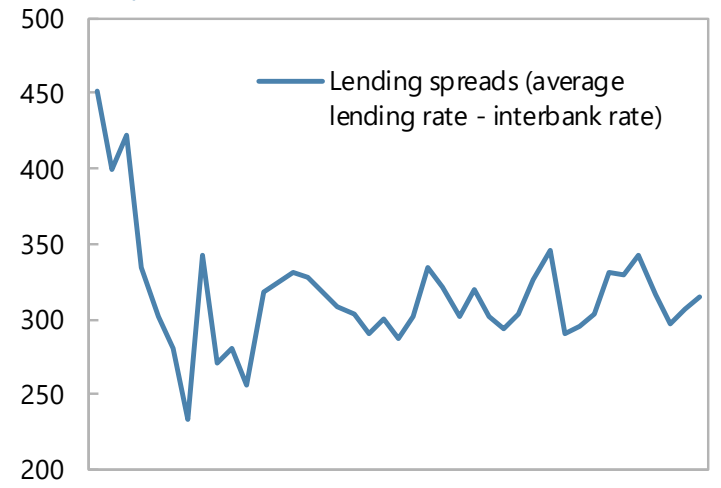

2006Q02 2008Q02 2010Q02 2012Q02 2014Q02 2016Q02

Exchange rate pass-through remains strong (Year-on-year rate of growth)

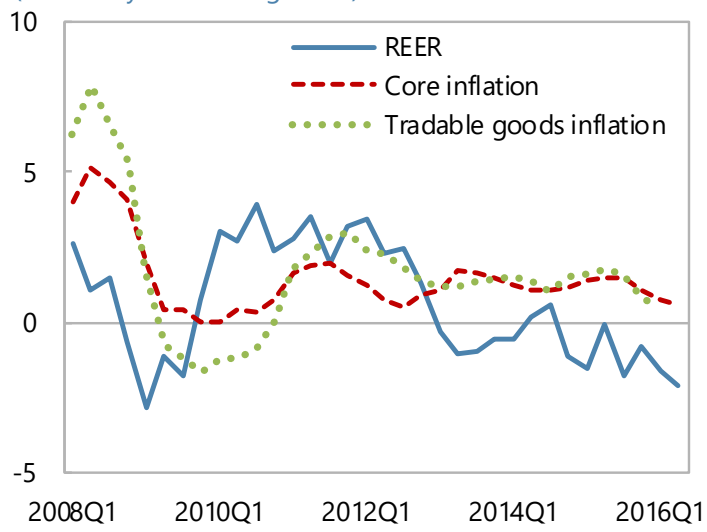

Source: National data and MQPM database. 


\section{The Moroccan Quarterly Projection Model (MQPM)}

\section{A. A model for transition}

The MQPM is expected to support BAM's monetary policy decision making during the gradual transition toward a more flexible exchange rate regime and eventual adoption of fullfledged inflation targeting. ${ }^{10}$ To this end, the model was designed to accommodate both the existing fixed exchange rate framework with capital controls (Mundell, 1963) and an alternative of a floating exchange rate and gradually increasing capital mobility. ${ }^{11}$ The fixed exchange rate framework has required a few novel technical solutions to capture the Moroccan features discussed earlier, such as the importance of the agricultural sector, the semi-closed capital account, and the link between the monetary stance and international reserves, all of which will be described in this section.

The main difference between the two regimes is in their choice of the long-run nominal anchor. In the fixed exchange rate regime, the anchor is the nominal exchange rate, while other nominal variables - inflation and nominal interest rates - are determined endogenously. In the flexible regime, it is the long-term rate of inflation, as defined by an explicit inflation target, that serves as the nominal anchor, and the other nominal variables are determined endogenously. Technically, the model code allows for a switch between the two regimes by changing the structure and parametrization of key equations describing the behavior of the nominal variables. The key differences between the two regimes are captured in two blocks of the model: the exchange rate and interest rate equations, while all other behavioral equations remain unchanged between the regimes at this stage.

The MQPM structure and calibration replicate the comparatively high persistence of the key macroeconomic variables in the Moroccan economy. As mentioned earlier, terms of trade and domestic demand shocks have been addressed primarily through long-lasting internal devaluations. The fixed exchange rate regime coupled with non-aggressive responses of monetary and fiscal policy tools to domestic cyclical developments and external shocks has resulted in slower-than-usual returns to the system's steady state. In the next two sections we provide several impulse responses to typical macroeconomic shocks that show the model economy returning to its steady state in about 16 quarters, that is, about four-to-six quarters more slowly than in more open economies.

\footnotetext{
${ }^{10}$ The two versions of the MQPM were developed for the transition from the fixed to a floating exchange rate regime, rather than for the move from a relatively closed to a relatively open capital account. The latter transition will involve a number of channels that are not featured in the current MQPM, see IMF (2012).

${ }^{11}$ The framework will eventually require full reassessment and recalibration to reflect long-term modifications to agents' behavior under the new regime to be ready for the adoption of a full-fledged inflation-forecasttargeting regime. For a discussion of critical ingredients of IFT regimes see Clinton and others (2015a, b and 2017), Obstfeld and others (2016), and Alichi and others (2015a and b). Critical extensions include nonlinearities in the output-inflation process, see Laxton, Rose and Tetlow (1993), Laxton, Ricketts and Rose (1993), Eliasson and others (1999), Clark, Laxton and Rose (1995), Alichi and others (2009), and Argov and others (2007). For a discussion of models that include macroprudential policy issues see Benes and others (2014).
} 
Table 1. Modeling Solutions to Regime Differences

\begin{tabular}{|c|c|c|}
\hline & Fixed exchange rate regime & Flexible exchange rate regime \\
\hline $\begin{array}{l}\text { Nominal } \\
\text { exchange } \\
\text { rate }\end{array}$ & $\begin{array}{l}\text { The nominal exchange rate is an exogenous } \\
\text { policy choice variable and without an ad hoc } \\
\text { policy decision its value does not change. }\end{array}$ & $\begin{array}{l}\text { The nominal exchange rate is } \\
\text { determined by investors' portfolio } \\
\text { choice, reflecting the expected } \\
\text { relative return of domestic assets, } \\
\text { proxied by the money-market } \\
\text { interest rate differential adjusted for } \\
\text { the risk premium. The arbitrage } \\
\text { condition is described by the risk- } \\
\text { adjusted uncovered interest rate } \\
\text { parity condition, UIP. }\end{array}$ \\
\hline $\begin{array}{l}\text { Domestic } \\
\text { interest } \\
\text { rate }\end{array}$ & $\begin{array}{l}\text { Limited capital mobility gives the central bank } \\
\text { some independence to influence the money- } \\
\text { market rates. The policy reaction function has } \\
\text { two notable features. First, it is highly persistent } \\
\text { and inflation aversion is relatively weak. } \\
\text { Second, the overall relative asset price is a } \\
\text { hypothetical "interest rate" that reflects the fact } \\
\text { that most domestic agents borrow at "domestic" } \\
\text { rates, while only some can borrow at "foreign" } \\
\text { rates. The overall interest rate is then set as a } \\
\text { weighted average of the BAM policy rate and } \\
\text { the UIP-implied rate, that is, the "foreign" } \\
\text { interest rate plus the risk premium. }\end{array}$ & $\begin{array}{l}\text { The domestic interest rate is the } \\
\text { main policy instrument and it is } \\
\text { modeled as the standard inflation- } \\
\text { forecast based reaction function } \\
\text { (Clark, Laxton, and Rose, 2001; } \\
\text { Berg, Karam, and Laxton, 2006a, } \\
\text { b). It describes a policymaker } \\
\text { stabilizing inflation around the } \\
\text { target and minimizing shortfalls in } \\
\text { capacity utilization. }\end{array}$ \\
\hline
\end{tabular}

Source: MPQM.

The flexible exchange rate version of the MQPM is better able to stabilize the economy when faced with real external shocks than the fixed exchange rate version of the model. When buffeted with shocks to external variables such as foreign demand, remittances, terms of trade, or import prices, the flexible exchange rate model economy returns faster to its steady state, with smaller output losses. Intuitively, the nominal exchange rate serves as an efficient shock absorber when allowed to adjust to the external environment changes, aided by less persistent domestic interest rates. The relative real prices can thus adjust more quickly, facilitating the necessary expenditure switching between domestic and foreign goods. We demonstrate the difference between the two regimes with the impulse responses to a one percentage point shock to euro zone inflation (Figure 3).

\section{B. Special Features of the Moroccan QPM Model}

In this section, we focus on the specific features of the fixed exchange rate version of the MQPM. While broadly following Berg, Karam, and Laxton (2006a), the MQPM contains a more detailed representation of the demand side of the economy and a modified UIP and reaction functions (Table 2). Furthermore, the calibration of the MQPM reflects the high persistence of key macroeconomic variables as observed in the data. Benlamine and others (forthcoming) document additional impulse responses. 


\section{Figure 3. A Positive One-Percent shock to Euro Area Inflation}

A positive one percentage point shock to euro zone inflation leads to higher imported inflation that increases domestic inflation. Under a flexible exchange rate regime and inflation targeting the policymaker is more averse to inflation and the policy rate increase is bigger than that in the fixed exchange rate regime. Furthermore, the movement of the nominal exchange rate helps to absorb more rapidly the shock coming from imported inflation than in the fixed regime, where the adjustment is done through sticky domestic prices.
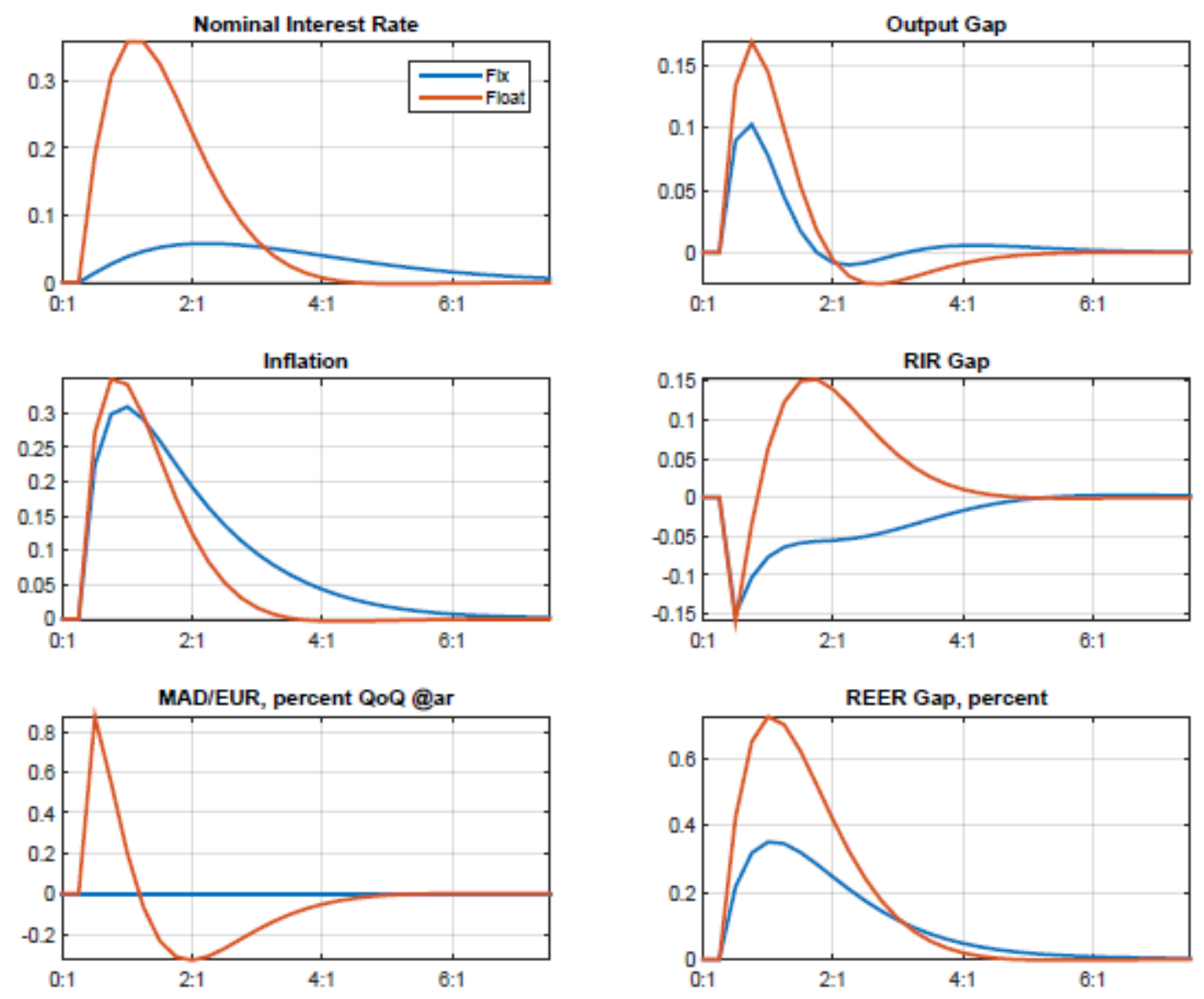

Notes: The output gap is defined as percent deviation of actual GDP to its potential; inflation is defined as annualized quarter-on-quarter percent change of the CPI; the real effective exchange rate (REER) gap is defined as a percent deviation of the actual real exchange rate to its trend value; and the real effective interest rate gap (RIR) is defined as a percent deviation of the weighted average of the BAM policy rate and the UIP-implied rate to its trend value.

Source: Authors' simulations.

First, the aggregate demand block reflects the importance of agricultural production in Morocco. On the one hand, agriculture's share on both value added and employment has remained high. On the other hand, weather-related shocks contributed to GDP and household income volatility, affecting economy-wide demand decisions. Hence, agricultural output is 
included in the equations describing households' consumption and investment decisions. Second, remittances from abroad constitute a large and relatively stable share of household income, thus directly affecting consumption decisions. To this end, remittances are included in the consumption equation, along with other sources of household income.

Third, the private sector saving and investment decisions are influenced by the effective interest rate, which is calculated as a weighted average of the domestic policy rate and the UIP-implied rate. The latter is a hypothetical interest rate that would correspond to the international financing costs under full capital mobility. Fourth, the risk premium is inversely related to the international reserve coverage ratio. Intuitively, the more international reserves the central bank possesses the more room for maneuver it has to defend the exchange rate parity through quantitative interventions as opposed through policy rate adjustments. With a higher reserve-coverage ratio, domestic assets are deemed less risky, and external financing costs, reflected in the UIP-implied interest rate, are reduced.

Table 2. The MQPM Structure Under the Fixed Exchange Rate Regime

\begin{tabular}{|c|c|c|}
\hline & Canonical QPM & MQPM \\
\hline $\begin{array}{l}\text { IS } \\
\text { curve }\end{array}$ & $\begin{array}{l}\hat{y}_{t}=a_{1} \hat{y}_{t-1}+a_{2} m c i_{t}+a_{3} \hat{y}_{t}^{*}+\varepsilon_{t}^{y} \\
m c i_{t}=b_{4} \hat{r}_{t}+\left(1-b_{4}\right)\left(-\hat{z}_{t}\right)\end{array}$ & 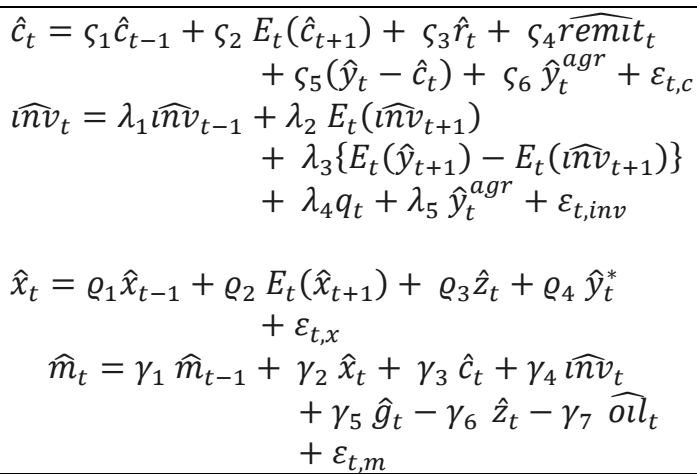 \\
\hline UIP & $s_{t}=E_{t} s_{t+1}+\left(i_{t}^{*}-i_{t}+\right.$ prem $\left._{t}\right) / 4+\varepsilon_{t}^{s}$ & $S_{t}=S_{t-1}+\varepsilon_{t, S}$ \\
\hline $\begin{array}{l}\text { Policy } \\
\text { rule }\end{array}$ & $i_{t}=g_{1} i_{t-1}+\left(1-g_{1}\right)\left(i_{t}^{n}+g_{2}\left(E_{t} \pi_{t+4}-\pi_{t+4}^{T}\right)+g_{3} \hat{y}_{t}\right)+\varepsilon_{t}^{i}$ & $\begin{array}{c}i_{t}=\alpha_{1} i p_{t-1}+\left(1-\alpha_{1}\right)\left(\overline{l p}_{t}+\alpha_{2} \pi_{t+3}^{d e v}\right. \\
\left.+\alpha_{3} \overline{d d}_{t}\right)+\varepsilon_{t, i p} \\
\text { iuip }_{t}=i_{t}^{e z}+\text { prem }_{t}+\left(E_{t}\left(\text { mad }_{\text {eur }} \text { eur }_{t+1}\right)\right. \\
-{\left.\text { mad } / \text { eur }_{t}\right)}^{i_{t}=\omega_{i p} i_{t}+\left(1-\omega_{\text {ip }}\right) \text { iuip }_{t}}\end{array}$ \\
\hline $\begin{array}{l}\text { Philips } \\
\text { Curve }\end{array}$ & $\begin{array}{l}\pi_{t}=a_{1} \pi_{t-1}+\left(1-a_{1}\right) E_{t} \pi_{t+1}+a_{2} r m c_{t}+\varepsilon_{t}^{\pi} \\
r m c_{t}=a_{3} \hat{y}_{t}+\left(1-a_{3}\right) \hat{z}_{t}\end{array}$ & $\begin{aligned} \pi_{t}^{\text {core }}=\beta_{1} \pi_{t-1}^{\text {core }} & +\left(1-\beta_{1}\right) E_{t}\left(\pi_{t+1}^{\text {core }}\right) \\
& +\beta_{2} \text { rmc core }+\beta_{3} \pi_{t}^{\text {vf }} \\
& +\varepsilon_{t, \text { core }} \\
\pi_{t}^{\text {reg }}=\delta_{1} \pi_{t-1}^{\text {reg }}+ & \left(1-\delta_{1}\right) E_{t}\left(\pi_{t+1}^{\text {core }}\right)+\delta_{3} \widehat{g}_{t} \\
& +\varepsilon_{t, \text { admin }} \\
\pi_{t}^{\text {fuel }}=\eta_{1} \pi_{t-1}^{\text {fuel }} & +\left(1-\eta_{1}\right) s s_{\pi} \text { fuel }+\eta_{2} \widehat{\text { oll }}_{t} \\
& +\varepsilon_{t, \text { fuel }}\end{aligned}$ \\
\hline
\end{tabular}

Note: For abbreviations, please see Annex III.

Source: Berg, Karam, and Laxton (2006a, b) and the MQPM under the assumption of a fixed exchange rate. 


\section{Selected Impulse Response Functions}

In this part, we explore the impulse responses to three positive monetary-policy relevant shocks: to aggregate demand, prices, and exchange rate (devaluation).

\section{Aggregate demand}

A positive shock to household consumption (Figure 4) stimulates aggregate demand and creates inflationary pressures. As the nominal exchange rate is fixed, higher inflation appreciates the dirham real exchange rate and decreases demand for Morocco's net exports. Although the monetary authority increases the domestic interest rate somewhat as inflation is expected to exceed the BAM long-run implicit price objective, the real interest rate remains negative for the first couple of quarters. Thus, it is mostly the long-lasting appreciation of the real exchange rate that gradually offsets the excess demand and returns inflation to its implicit target.

Figure 4. An Increase in Household Consumption

(All variables are expressed as percent deviations from the steady state)
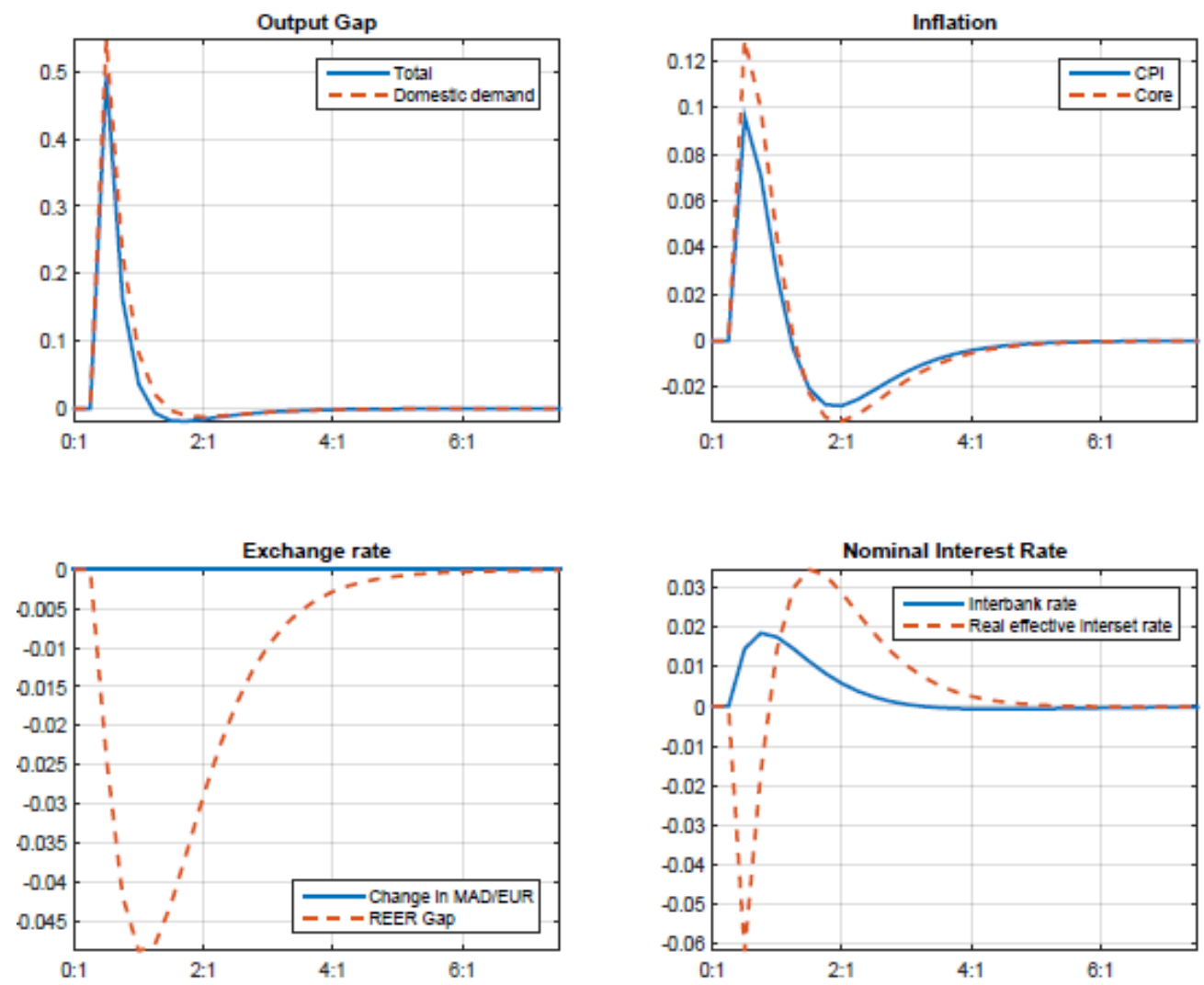

Source: Authors' simulations. 


\section{Prices}

A positive exogenous increase in core inflation, such as due to a mark-up shock, results in a swift rise in domestic prices (Figure 5). The sluggish response of monetary policy initially boosts aggregate demand as the real interest rate turns negative - the increase in inflation is initially much larger than that of the policy rate. The adjustment process is therefore mostly through the exchange rate channel. First, domestic inflation appreciates the dirham in real terms, starting an expenditure switching process towards foreign goods and away from the domestic ones. The associated decrease in net exports holds back aggregate demand, reversing the initial excess capacity. Second, prices of imported goods remain constant in dirham terms, exerting downward prices on domestically produced goods. Thus, weaker demand coupled with lower cost pressures eventually corrects the inflationary shock.

\section{Figure 5. An Increase in Domestic Inflation}

(All variables are expressed as percent deviations from the steady state)
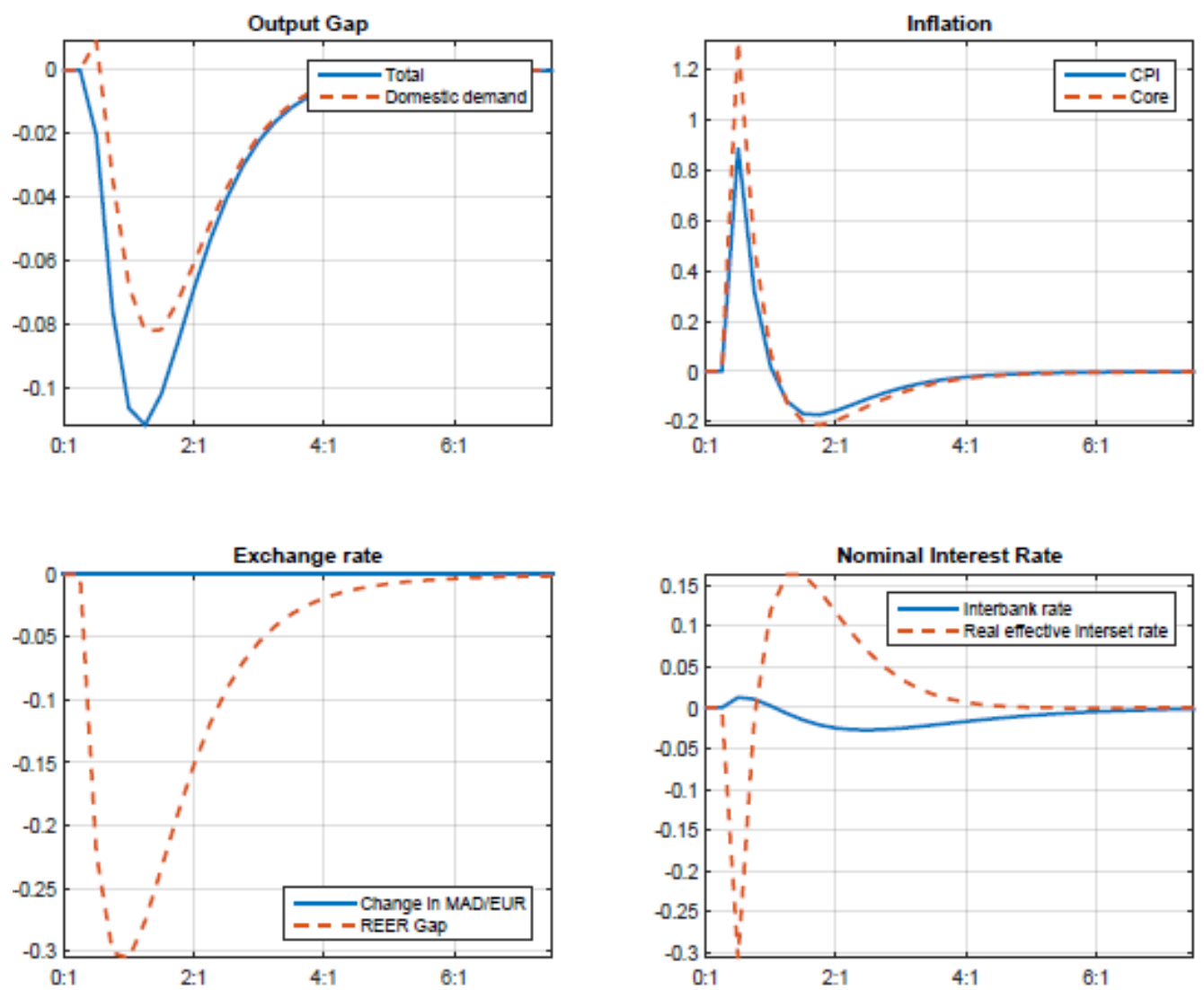

Notes: The output gap is defined as percent deviation of actual GDP to its potential; inflation is defined as annualized quarter-on-quarter percent change of the headline and core price indexes; the real effective exchange rate (REER) gap is defined as a percent deviation of the actual real exchange rate to its trend value; and the real effective interest rate is defined as a weighted average of the BAM policy rate and the UIP-implied rate.

Source: Authors' simulations. 


\section{Exchange rate}

A positive change in the nominal exchange rate - dirham devaluation - would have both inflation and output effects (Figure 6). First, the increase in import prices in domestic currency terms is passed through to headline inflation. Second, devaluation improves Moroccan net exports by making exports more price competitive and foreign products more expensive for domestic consumers, creating excess demand and price pressures. Only after some 16 quarters the domestic price level permanently adjusts to the devaluation shock - the long-term exchange rate pass-through is equal to one.

\section{Figure 6. Nominal Devaluation}

(All variables are expressed as percent deviations from the steady state)
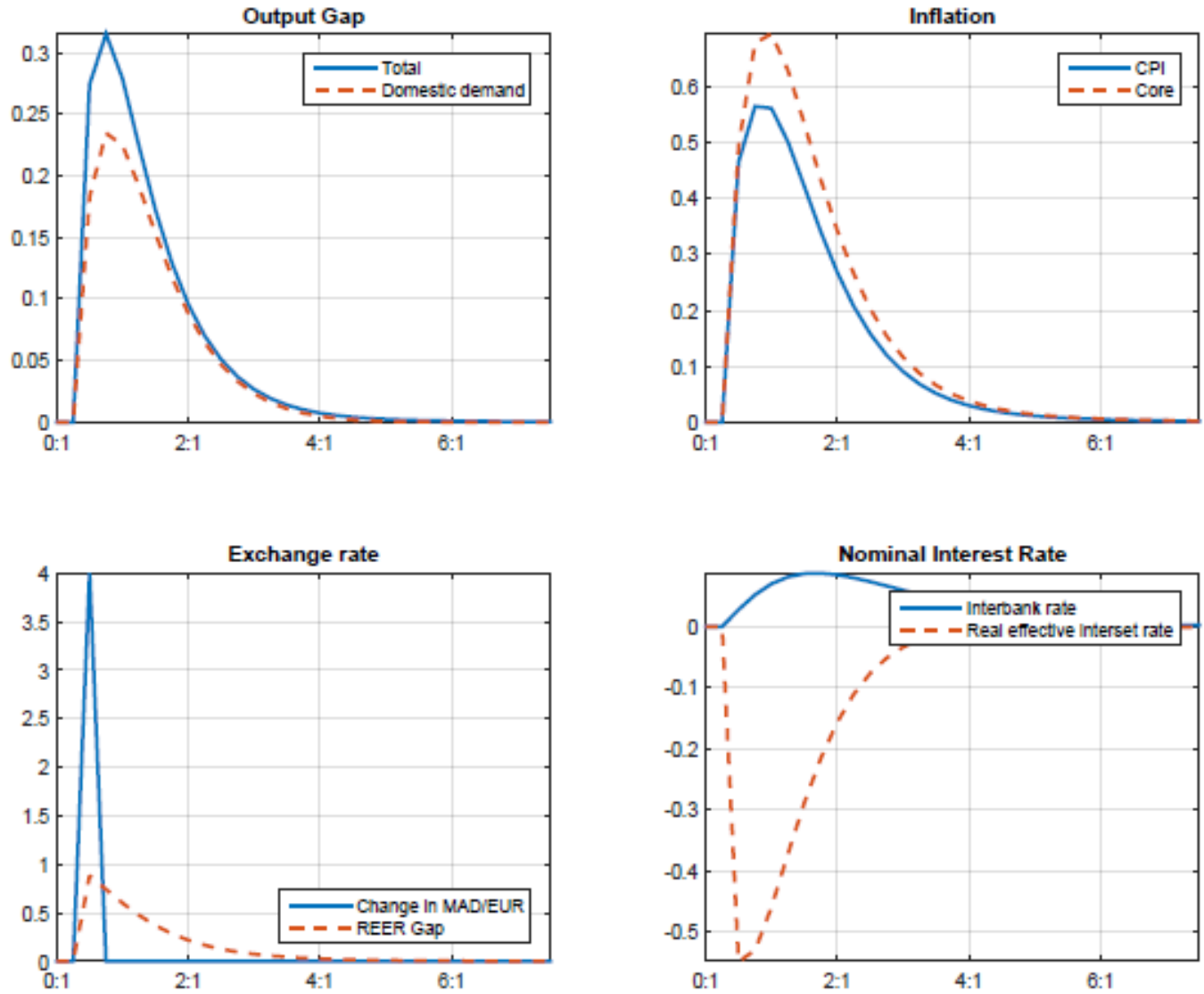

Notes: The output gap is defined as percent deviation of actual GDP to its potential; inflation is defined as annualized quarter-on-quarter percent change of the headline and core price indexes; the real effective exchange rate (REER) gap is defined as a percent deviation of the actual real exchange rate to its trend value; and the real effective interest rate is defined as a weighted average of the BAM policy rate and the UIP-implied rate.

Source: Authors' simulations.

\section{Conclusions And the Policy Uses of The QPM in Morocco}

Starting in 2014, the Bank Al-Maghrib began amending its analytical framework and improving processes to support monetary policy decision-making with the assistance of IMF 
Research Department and TA experts. The new Forecasting and Policy Analysis System is centered around a semi-structural macroeconomic model tailored for the Moroccan economy, called the Moroccan Quarterly Projection Model. The fixed exchange rate framework required several novel technical solutions to capture features specific to the Moroccan economy, such as the importance of the agricultural sector and remittances for household decisions, limited capital mobility, and a link between the risk premium and international reserves. From 2016, the MQPM has been used as the core model in the macroeconomic projection exercise and policy analysis of the BAM. Building an FPAS under a familiar, pegbased regime allowed the technical staff and managers to gain familiarity with the new processes. The positive feedback received from the BAM policymakers is that the FPAS has provided a rich platform for policy discussion.

The key advantage of the MQPM is the assessment of the monetary policy stance and possibility to compare alternative scenarios and risk assessments. The MQPM has provided a common language between the staff and management owing to the framework flexibility, intuitive nature, and ability to capture Morocco specific features. BAM's management appreciated that the MQPM-based forecasts tell a consistent, forward-looking story making policy decision-making forward-looking as well.

The test for the MQPM team will be the transition to a more flexible exchange rate as outlined in IMF (2016a). First, as the monetary policy framework is expected to eventually shift toward a more flexible exchange rate and inflation-forecast targeting, the policy reaction function will need to be refined to reflect the policymaker's behavior and to provide sensible policy advice. Policymakers' behavior under the current fixed exchange rate regime will provide limited guidance for the new regime, given the past limited use of interest rate changes. Second, the speed of further capital account liberalization and its impact on exchange rate developments and monetary policy remains uncertain. Third, the rapid expansion of export-oriented sectors and other structural changes in the Moroccan economy will have profound impact on economic growth and employment. These developments will change Morocco's convergence vis-à-vis its developed-country trading partners and affect the MQPM steady-state behavior. Finally, all these changes will affect the transmission mechanism and will need to be gradually reflected in the MQPM. 


\section{REFERENCES}

Alichi, A., K. Clinton, C. Freedman, O. Kamenik, M. Juillard, D. Laxton, J. Turunen, and H. Wang, 2015a, “Avoiding Dark Corners: A Robust Monetary Policy,” IMF Working Paper 15/134. Available at: https://www.imf.org/external/pubs/ft/wp/2015/wp15134.pdf.

Alichi, A., J. Benes, J. Felman, I. Feng, C. Freedman, D. Laxton, E. Tanner, D. Vavra, H. Wang, 2015b, "Frontiers of Monetary Policymaking: Adding the Exchange Rate as a Tool to Combat Deflationary Risks in the Czech Republic,” IMF Working Paper 15/74. Available at: https://www.imf.org/external/pubs/ft/wp/2015/wp1574.pdf.

Alichi, A., H. Chen, K. Clinton, C. Freedman, M.J. Johnson, O. Kamenik, T. Kisinbay, and D. Laxton, 2009, “Inflation Targeting Under Imperfect Policy Credibility,” IMF Working Paper 09/94. Available at: https://www.imf.org/ /media/Websites/IMF/imported-full-textpdf/external/pubs/ft/wp/2009/_wp0994.ashx.

Argov, E., N. Epstein, P. Karam, D. Laxton, and D. Rose, 2007, “Endogenous Monetary Policy Credibility in a Small Macro Model of Israel,” IMF Working Paper 07/207. Available at: https://www.imf.org/external/pubs/ft/wp/2007/wp07207.pdf.

Bank Al-Maghrib, 2016, Strategic Plan 2016-2018, (Rabat: Bank Al-Maghrib). Available at: http://www.bkam.ma/en/content/download/18448/2700740/PS\%2020162018\%20ANG.pdf.

Benazzi, R., 2017, “Analyse de la concurrence bancaire au Maroc : Approche de Panzar et Rosse”, BAM Working Paper. Available at: http://www.bkam.ma/content/download/537373/5660379/version/1/file/Document+1Analyse+de+la+concurrence+bancaire+au+Maroc ++Approche+de+Panzar + et + Rosse .pdf.

Benes, J., M. Kumhof, and D. Laxton, 2014, “Financial Crises in DSGE Models: A Prototype Model,” IMF Working Paper 14/57. Available at: https://www.imf.org/external/pubs/ft/wp/2014/wp1457.pdf

Benlamine M., H. El Idrissi, M. Farouki, A. Horvath, Z. Iraoui, A. Maaroufi, forthcoming, “The Moroccan Quarterly Projection Model”, BAM Working Paper.

Berg, A., P. Karam, and D. Laxton, 2006a, “Practical Model-Based Monetary Policy Analysis - Overview,” IMF Working Paper 06/80. Available at: https://www.imf.org/external/pubs/ft/wp/2006/wp0680.pdf 
2006b, "Practical Model-Based Monetary Policy Analysis — A How-To

Guide,” IMF Working Paper 06/81. Available at:

https://www.imf.org/external/pubs/ft/wp/2006/wp0681.pdf

Bouzahzah M., and R. Bachar, 2014, "Exchange Rate Policy in Morocco and Persistence of Real Exchange Rate Misalignments”, International Journal of Economics and Financial Issues, (4), No. 1, pp.122-134.

Brixiova, Z., and N. Mthuli, 2013, "Remittances and their Macroeconomic Impact: Evidence from Africa,” African Development Bank Group, Paper No. 188.

Bulír, A., and J. Vlček, 2015, "Monetary Transmission: Are Emerging Market and LowIncome Countries Different?” IMF Working Paper 15/239. Available at: https://www.imf.org/external/pubs/ft/wp/2015/wp15239.pdf

Clark, P., D. Laxton, and D. Rose, 1995, "Capacity Constraints, Inflation and the Transmission Mechanism: Forward-Looking Versus Myopic Policy Rules,” IMF Working Paper 95/75. Available at: https://www.imf.org/external/pubs/cat/longres.aspx?sk=1271.0

Clark, P., D. Laxton, and D. Rose, 2001, "An Evaluation of Alternative Monetary Policy Rules in a Model with Capacity Constraints," Journal of Money Credit and Banking, (33), No. 1, pp. 42-64.

Clinton, K., T. Hlédik, T. Holub, D. Laxton, and H. Wang, 2017, "Czech Magic: Implementing Inflation-Forecast Targeting at the CNB,” IMF Working Paper 17/21. Available at: https://www.imf.org/en/Publications/WP/Issues/2017/01/30/CzechMagic-Implementing-Inflation-Forecast-Targeting-at-the-CNB-44604

Clinton, K., C. Freedman, M. Juillard, O. Kamenik, D. Laxton, and H. Wang, 2015a, "Inflation-Forecast Targeting: Applying the Principle of Transparency," IMF Working Paper 15/132. Available at: https://www.imf.org/external/pubs/ft/wp/2015/wp15132.pdf

Clinton, K. C. Freedman, M. Juillard, O. Kamenik, D. Laxton, and H. Wang, 2015b, "Inflation Forecast Targeting: Applying the Principle of Transparency," IMF Working Paper 15/132 Supplemental Annex. Available at: https://www.imf.org/en/Publications/WP/Issues/2016/12/31/Inflation-ForecastTargeting-Applying-the-Principle-of-Transparency-43023

Edwards, S., and E. Levy Yeyati, 2005, "Flexible Exchange Rates as Shock Absorbers," European Economic Review, (49), November, pp. 2079-2105.

Eliasson, A., P. Isard, and Douglas Laxton, 1999, "Simple Monetary Policy Rules Under Model Uncertainty," in International Finance and Financial Crises: Essays in Honor 
of Robert P. Flood, Jr., ed. by P. Isard, A. Razin, and A. K. Rose (Washington DC: International Monetary Fund).

IMF, 2012, The Liberalization and Management of Capital Flows: An Institutional View, (Washington DC: International Monetary Fund).

IMF, 2015a, Evolving Monetary Policy Frameworks in Low-Income and Other Developing Countries, (Washington DC: International Monetary Fund).

IMF, 2015b, Annual Report on Exchange Arrangements and Exchange Restrictions, (Washington DC: International Monetary Fund).

IMF, 2016a, Morocco: 2015 Article IV Consultation-Staff Report, (Washington DC: International Monetary Fund).

IMF, 2016b, Morocco: Financial System Stability Assessment, (Washington DC: International Monetary Fund).

Klein, M. W., and J. C. Shambaugh, 2013, "Rounding the Corners of the Policy Trilemma: Sources of Monetary Policy Autonomy,” NBER Working Paper No. 19461. Available at: http://www.nber.org/papers/w19461.pdf.

Kaminsky, G. L., C. M. Reinhart, and C. A. Vegh, 2004, "When It Rains, It Pours: Procyclical Capital Flows and Macroeconomic Policies,” NBER Working Paper No. 10780. Available at: http://www.nber.org/papers/w10780.pdf.

Laxton, D., D. Rose, and R. Tetlow, 1993, “Monetary Policy, Uncertainty and the Presumption of Linearity,” Technical Report No. 63, (Ottawa: Bank of Canada).

Laxton, D., N. Ricketts, and D. Rose, 1993, "Uncertainty, Learning and Policy Credibility,” Economic Behavior and Policy Choice Under Price Stability, Proceedings of a Conference held at the Bank of Canada, 30-31 October. www.douglaslaxton.org/sitebuildercontent/sitebuilderfiles/LRR.pdf

Mundell, R. A., 1963, “Capital Mobility and Stabilization Policy under Fixed and Flexible Exchange Rates,” Canadian Journal of Economic and Political Science, (29), pp. 475-485.

Obstfeld, M., and A. M. Taylor, 1997, “The Great Depression as a Watershed: International Capital Mobility over the Long Run,” NBER Working Paper No. 5960. Available at: http://www.nber.org/papers/w5960.pdf.

Obstfeld, M. K. Clinton, O. Kamenik, D. Laxton, Y. Ustyugova and H. Wang, 2016, “How to Improve Inflation Targeting in Canada,” IMF Working Paper 16/192. Available at: https://www.imf.org/external/pubs/ft/wp/2016/wp16192.pdf. 
Obstfeld, M., J. C. Shambaugh, and A. M. Taylor, 2005, “The Trilemma in History: Tradeoffs among Exchange Rates, Monetary Policies, and Capital Mobility,” Review of Economics and Statistics, (87), pp. 423-38.

Obstfeld, M., and K. Rogoff, 1995, “Exchange rate dynamics redux,” Journal of Political Economy, (103), pp. 624-660.

Reinhart, C., and V. Reinhart, 2008, “Capital Flow Bonanzas: An Encompassing View of the Past and Present,” NBER Working Paper No. 14321. Available at: http://www.nber.org/papers/w14321.pdf

Rey, H., 2010, Financial Stability, the Trilemma, and International Reserves. American Economic Journal: Macroeconomics, pp. 57-94.

, 2013, "Dilemma not Trilemma: The Global Financial Cycle and Monetary Policy Independence,” In: Global Dimensions of Unconventional Monetary Policy, Kansas City Federal Reserve, pp. 285-333.

Taamouti M., 2015, "Background Paper on Monetary Policy - The Kingdom of Morocco,” AMF-BIS Working Paper, pp. 160-175. Available at: http://www.amf.org.ae/sites/default/files/research_and_publications/\%5Bvocab\%5D/ \%5Bterm\%5D/\%5Blanguage\%5D/AMF\%20CONSOLIDATED\%20BOOK.pdf

Zottel, S., C. R. Ortega, D. Randall, and S. Yan Xu, 2014, Enhancing Financial Capability and Inclusion in Morocco: A Demand-side Assessment. (Washington, DC: World Bank Group). 


\section{ANNEX I. FPAS Technical Assistance in Morocco}

The Moroccan authorities began considering an alternative to the exchange rate peg during the early 2000s as the liberalization of the economy is going forward. In mid-2000s the Bank Al-Maghrib and the IMF co-organized a conference on inflation targeting that provided an initial impetus for the regime change. While the progress temporarily stalled during the Great Recession, the authorities' commitment to a flexible exchange rate and inflation targeting was repeatedly restated. Contrary to peg-to-IT switches in other emerging market countries that typically happened under duress, Morocco has faced no external pressures to abandon the peg and the regime choice has been purely internal.

In 2014 the Government of Canada provided a multi-year grant to fund technical assistance in the area of macroeconomic modeling and forecasting to support the gradual switch to inflation targeting. IMF's Research Department worked with the BAM to develop a forecasting and policy analysis system for Morocco and backstopped the technical experts, most of whom were former staff of the Czech National Bank and Magyar Nemzeti Bank. The technical assistance project encompassed beside modeling also central bank communication and motivated modifications to operational processes at the BAM. Additional technical assistance was provided by the IMF's Monetary and Capital Markets Department. The BAM 2016-2018 Strategic Plan incorporated the thrust of these recommendations (Bank AlMaghrib, 2016).

From the onset, the process of making the dirham more flexible and introducing inflation targeting was to be a gradual one. Importantly, the key elements of the FPAS were to be in place before the regime switch and the BAM staff thus initially developed a framework reflecting the existing regime. This phase lasted from 2014 to 2016 and the BAM leaned heavily on the external experts, who facilitated learning by the BAM staff. Starting with the March 2016 forecast round, this framework provided policy analysis and forecasts for the BAM Board monetary policy decisions. The FPAS introduction was fairly successful, in large part due to willingness to adjust the organization of the bank in response to the framework's needs. For example, the roles of several key departments were changed, new divisions were created, and responsibilities were re-assigned.

Subsequently, the BAM staff and TA experts started developing a parallel analytical and forecasting model that would embody the most likely features of the Moroccan economy after dirham flexibility will have been increased. The flexible exchange rate FPAS framework could be switched on immediately after the policy decision. In the interim, the BAM staff has been preparing quarterly baseline scenarios using the pegged-regime model and alternative scenarios using the managed floating-regime model. The above two-pronged approach allowed the technical staff and managers to gain familiarity with the FPAS under the familiar peg-based regime.

The Morocco FPAS TA project provides a useful model for other emerging market or lowincome countries that consider a gradual switch to inflation targeting, but do not have the 
necessary technical and organizational framework in place. The experience of Morocco shows that such countries can establish an FPAS using the current regime, gradually building skills to operate the framework and preparing the policymaker for a regime change. The eventual switch is likely to be less traumatic than that performed under duress. The length of the process of putting an FPAS in place will depend on a number of internal factors, such as, the technical preparedness of the staff, willingness of managers to experiment, policymakers' support, and so on, but is unlikely to last less than 24 months. 


\section{ANNEX II. Empirical Validation of the Model}

Historical simulations of the MQPM confirm that the model would have given reasonably accurate forecasts. The historical projections are presented using so-called spider charts to display the out-of-sample, 8-quarter-ahead evolution of the key model variables for the 20072015 period. In contrast to the regular forecasting process, no expert judgment is imposed in these historical simulations, that is, we present "pure" model simulations. Furthermore, given the lack of vintage, real-time data, we used the ex-post realizations of exogenous and external variables. Although the use of ex-post data improves the forecast performance of the MQPM relative to real-time data, it also makes the model "responsible" for all remaining "forecast errors.”

The out-of-sample simulations confirm the usefulness of the MQPM as a medium-term forecasting tool for policy decisions. The projected paths of the key macro variables are broadly in line with the ex-post data and the remaining deviations can be related to the differences between the model-based and the actual monetary policy decisions and out-ofmodel developments. We will assess the interbank rate, inflation, and domestic demand.

\section{Interbank rate}

The MQPM uses the interbank rate variable in lieu of a "policy rate” as the interbank rate captures BAM's effective policymaking intentions better than any other observed variable. On average, the spread between the policy and interbank rates has been small during the period under consideration, averaging some 25 basis points, and comparable to other emerging market countries (Bulíř and Vlček, 2015).

The simulations of the interbank rate (Figure A1) indicate lower-than-actual interbank rates after the Global Financial Crisis. Specifically, the MQPM would have suggested nominal interest rate cuts to the tune of 25-50 basis points during 2008-12 as a reaction to the negative external shocks that slowed down economic growth and lowered inflation to below 2 percent. In reality, the BAM reaction was more conservative than anticipated in her reaction function and the interbank rate remained broadly unchanged until 2014. Monetary loosening was effected through lower reserve requirements instead - the ratio was quickly cut from 16.5 percent to 6.0 percent. The policy rate was decreased by 50 basis points only in 2014 and the interbank rate declined in tandem. 


\section{Figure A1. Historical Simulations of the Interbank Rate (In percent)}

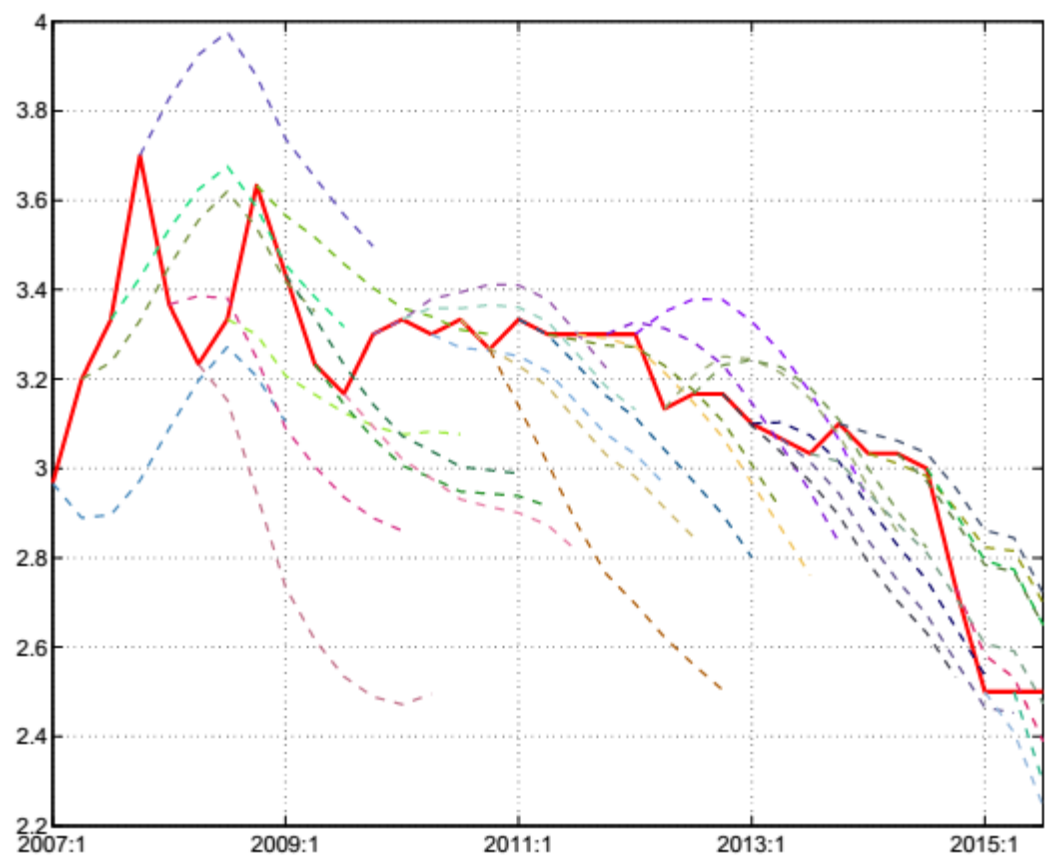

Notes: The historical simulations are out-of-sample, 8-quarter-ahead projections. No expert judgment is imposed and ex-post realizations of exogenous and external variables are used in lieu of near-term forecasts.

Source: Authors' simulations.

\section{Inflation}

Historic simulations fit core and headline inflation very well (Figure A2). Tight monetary conditions and a series of negative fiscal impulses during the period under consideration opened up a negative domestic demand gap and brought inflation down to zero during 2009. Inflation accelerated during 2010-11 mostly owing to a short-lived increase in non-volatile food prices (mostly cereals and cooking oil). Core inflation forecast errors were mostly related to a host of outside-of-the-model developments, such as, competition in the telecom sector driving down mobile service price. Headline inflation forecast errors were mostly related to non-core components, such as volatile food items. For example, much of the 2014 decline in headline CPI can be traced down to a drop in the prices of fresh vegetables and citrus fruits. 
Figure A2. Core and Headline Inflation Rates (In percent, year on year)
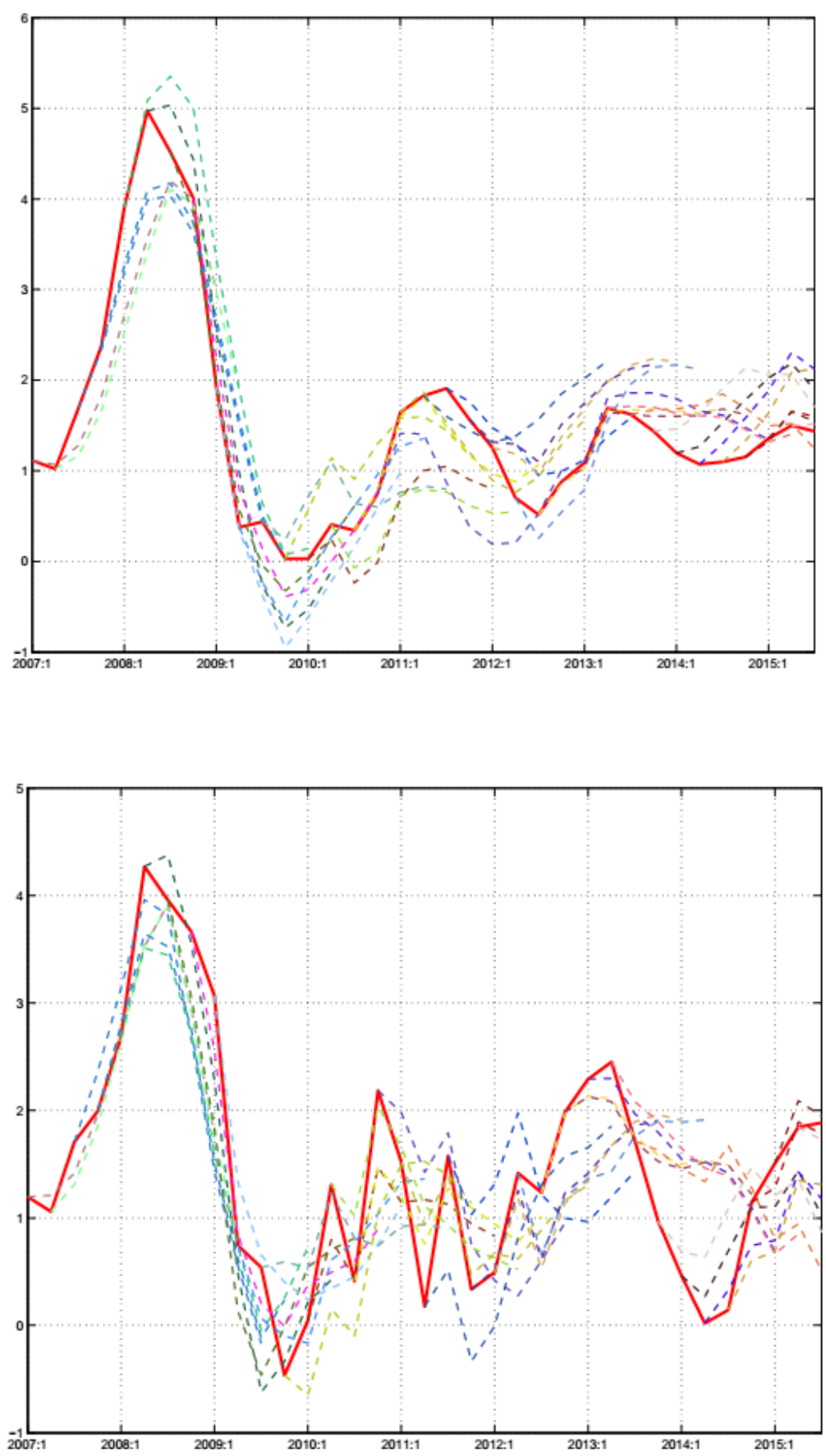

Notes: The historical simulations are out-of-sample, 8-quarter-ahead projections. No expert judgment is imposed and ex-post realizations of exogenous and external variables are used in lieu of near-term forecasts.

Source: Authors' simulations. 


\section{Domestic demand}

Historic simulations capture the turning points in domestic demand, but the observed series is too volatile to be fit well by a medium-term model (Figure A3). This volatility is primarily driven by weather conditions that affect agricultural developments that, in turn, affect both private consumption and investment. In addition, the MQPM struggled with properly accounting for the various post-2009 shocks, such as a decline in remittances; the negative domestic fiscal impulse that started in 2014; swings in oil and other commodity prices, and so on.

Figure A3. Domestic Demand Growth

(In percent, year on year)

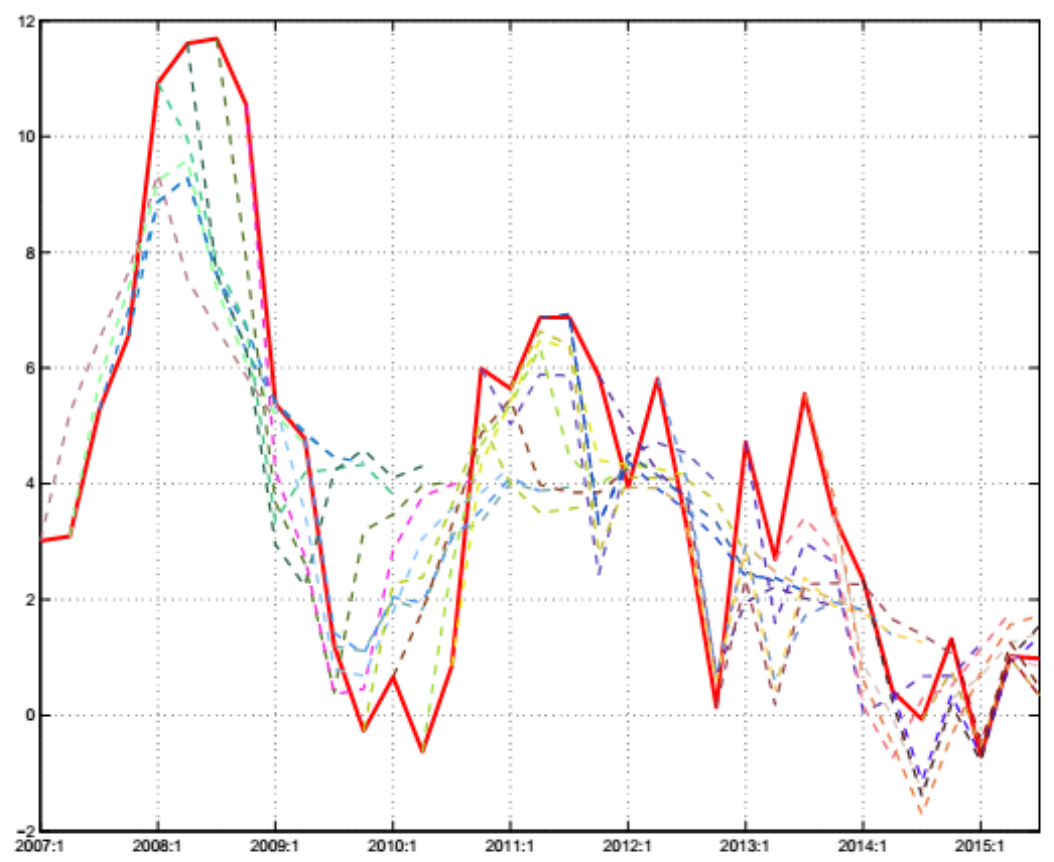

Notes: The historical simulations are out-of-sample, 8-quarter-ahead projections. No expert judgment is imposed and ex-post realizations of exogenous and external variables are used in lieu of near-term forecasts.

Source: Authors' simulations. 


\section{ANNEX III. Abbreviations Used in Table 2.}

\begin{tabular}{|c|c|}
\hline$i p_{t}$ & The interbank rate, representing the policy rate) \\
\hline$\overline{\imath p_{t}}$ & The natural rate of interest \\
\hline iuip $_{t}$ & UIP-implied interest rate \\
\hline prem $_{t}$ & The country risk premium \\
\hline$m c i_{t}$ & Monetary conditions index \\
\hline$\pi_{t}$ & Headline inflation \\
\hline$\pi_{t}^{\text {core }}$ & Core inflation \\
\hline$\pi_{t}^{\text {admin }}$ & Administered price changes \\
\hline$\pi_{t}^{v f}$ & Volatile fresh food price changes \\
\hline$\pi_{t+3}^{\text {dev }}$ & The $t+3$ period ahead deviation of the inflation rate from the implicit target \\
\hline $\mathrm{mad} / \mathrm{eur}$ & The dirham to euro nominal exchange rate \\
\hline$S_{t}$ & Nominal exchange rate \\
\hline$\hat{z}_{t}$ & The real exchange rate gap \\
\hline$r m c_{t}$ & Real marginal cost \\
\hline$y_{t}$ & Real GDP \\
\hline$\hat{y}_{t}$ & The output gap \\
\hline$\hat{y}_{t}^{\text {agr }}$ & The agricultural production gap \\
\hline$\hat{y}_{t}^{*}$ & The foreign output gap \\
\hline$\hat{c}_{t}$ & The real private consumption gap \\
\hline$\widehat{l n v}_{t}$ & The real investment gap \\
\hline$\hat{g}_{t}$ & The real government consumption gap \\
\hline$\hat{x}_{t}$ & The real exports gap \\
\hline$\widehat{m}_{t}$ & The real imports gap \\
\hline$\widehat{r e m i} t_{t}$ & The cyclical components of remittances from abroad \\
\hline$q_{t}$ & Tobin's $q$ \\
\hline$\widehat{\mathrm{Oll}}_{t}$ & International oil price \\
\hline$\widehat{d d}_{t}$ & The domestic demand gap \\
\hline
\end{tabular}

